\title{
DISTRIBUTION OF ZAKAT AND GRDP PER CAPITA IN SOUTH SULAWESI
}

\author{
A.Gustang 1 \\ Nasir Hamzah ${ }^{2}$ \\ Muslimin H Kara ${ }^{3}$ \\ Muh. Wahyuddin Abdullah ${ }^{4}$ \\ Alauddin State Islamic University of Makassar, Indonesia ${ }^{1,2,3,4}$ \\ agustang@uin-alauddin.ac.id
}

\begin{abstract}
This study purpose to test empirically the effect of consumptive ZIS distribution on the ZIS distribution for economic activities and the provision of capital and per capita GRDP. To test the effect of ZIS distribution for economic activities and capital providing on GDP per capita. To test the effect of the consumptive ZIS distribution on the GDP per capita through the ZIS distribution for economic activities and capital providing. The type of research used is quantitative with an explanatory approach. The study population was the districts and cities in South Sulawesi. The data used are: consumptive ZIS distribution, ZIS distribution for economic activities and capital providing and GRDP per capita according to the business fields and constant prices in the form of published documents. The sample used was 105 in the form of data panels consisting of 21 districts and cities using 5 years of documentation data (2015-2019). Data processing and analysis techniques use panel data regression statistical tests and path analysis using Eviews program data processing. The results showed that: (1) Increasing the distribution of consumptive ZIS can increase ZIS distribution for economic activities and capital providing and GRDP per capita. (2) Increasing the distribution of ZIS for economic activities and capital providing can increase GDP per capita. (3) Increasing the consumptive ZIS distribution can increase GDP per capita by increasing the ZIS distribution for economic activities and capital providing. The implication of the research results using the consumptive ZIS distribution approach model and the ZIS distribution for economic activities and the capital providing can be used as an instrument to increase GDP per capita directly and indirectly. This implication can be achieved by encouraging an increase in the consumptive ZIS distribution and the ZIS distribution for economic activities and the provision of capital as well as public awareness of the obligation of zakat.
\end{abstract}

Keywords: Zakat; Distribution; PDRB Perkapita

\section{INTRODUCTION}

At the beginning of the obligation of zakat, the implementation of zakat was handled by the Prophet. He sent his officers to collect zakat from people who were designated as zakat payers, then it was recorded, collected and guarded and finally distributed to the recipients of zakat (al-asnaf al-samanniyah). Rasulullah SAW was employed a young man from the Asad tribe, named Ibnul Lutaibah to take care of the zakat of the children of Solomon. He also sent Ali bin Abi Talib to Yemen to become amil zakat. Muaz bin Jabal was sent by the Messenger of Allah to go to 
Yemen, besides serving as a da'i (explaining Islamic teachings in general), he also had a special duty to be amil zakat. Thus, what the Khulafa Ar-rasyidin did afterward, they always had special officers who regulated zakat issues, both for their collection and distribution. Taking zakat from muzaki (people who have the obligation to give zakat) through amil zakat and then distributed to mustahik, shows that the zakat obligation is not merely charitable in nature, but also an obligation which is also authoritative in nature.

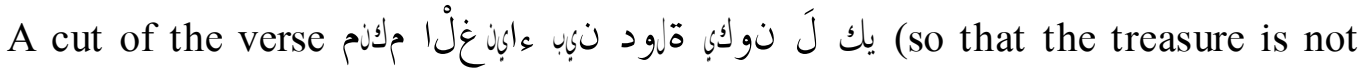
circulated among the rich only among you) so that the rich can rule over the poor. But Allah made it so that the treasure could revolve around them all ${ }^{1}$. This verse piece shows that Islam regulates the distribution of property so that it does not circulate only among the rich. Assets are not a means of controlling other people, so that these assets are not stored but can be produced by means of distribution. Wahbah AzZuhaili in the interpretation of Al-Wajis explains that the distribution of treasure aims not only to the rich people themselves, and he forbids poor people to accept their assets because they feel they really need it. The distribution of assets aims to prevent property from turning only to rich people who have fulfilled their needs ${ }^{2}$.

Economic development is often equated with economic growth which is usually measured by Gross Domestic Product (GDP) or Gross Regional Domestic Product (GRDP) which are used as the basis for measuring the economic success of a country or region, but it leaves problems that are sometimes underestimated. When economic growth occurs, the level of people's welfare should also increase, but in fact there are still many poor people, the gap is widening, the distribution of income is not evenly distributed and there is still a budget deficit. As in South Sulawesi Province, based on BPS data, economic growth based on GRDP growth is $7.23 \%$ higher than the national level growth, but the number of poor people has increased from 807,000 to 813,100 people in 2017.

Chaudry offers a solution in economic development, especially distribution problems with 12 instruments in Islam, where the instrument is based on the concept of alms. Alms that are meant include zakat, donations and alms ${ }^{3}$. Adel Sarea stated that zakat is the right index to measure economic growth through a number of methods ${ }^{4}$. Todaro stated that the basic problem of development is not how to grow Gross National Income (PNB), but the fundamental problem is who is involved in creating this growth ${ }^{5}$. If growth is the focus of development, when the growth is only caused by the rich, it will only be enjoyed by them. In other words, this growth meant nothing for the poor, and even resulted in the widening of the gap. Many areas experience high economic growth but do not provide significant benefits for the poor. Good economic growth is growth that is caused by all members of society in a

\footnotetext{
${ }^{1}$ Kemenag, “Quran,” 2021.

${ }^{2}$ Wahbah Az-Zuhaili, Fiqib Islam Wa Adillatubu, 1982.

${ }^{3}$ Muhammad Sharif Chaudhry and Suherman Rosyidi, Sistem Ekonomi Islam : Prinsip Dasar, Cet 1 (Jakarta: Kencana Prenada Media Group, 2012).

4 Adel Sarea, "Zakat as a Benchmark to Evaluate Economic Growth : An Alternative Approach," International Journal of Business and Social Science 3, no. 18 (2012): 242-45.

${ }^{5}$ Michael P. Todaro and Stephen C. Smith, Economic Developement, 2012.
} 
certain area and time. This has been proven by the results of OECD research that when income inequality increases, economic growth will fall by including the education variable as part of the factors that cause inequality ${ }^{6}$. Federico Cingano points out that income inequality has a negative and statistically significant impact on sustainable growth with a case study of 30 years in OECD countries ${ }^{7}$. Quality economic development is determined by the involvement of all parties in generating economic growth. The inclusion of more low-income communities in the development process will result in quality development.

Based on the description of the background of the problem above, in this paper we limit the discussion to the following problem formulation; Does the consumptive ZIS distribution affect the ZIS distribution for economic activities and capital provision? Does the distribution of consumptive ZIS affect per capita GRDP? Does the distribution of ZIS for economic activities and the provision of capital affect GRDP per capita? and Does the consumptive ZIS distribution affect per capita GRDP through the ZIS distribution for economic activities and capital provision?

This study aims to empirically examine the effect of the consumptive ZIS distribution on the ZIS distribution for economic activities and capital provision. Testing the effect of the consumptive ZIS distribution on GRDP per capita. To examine the effect of ZIS distribution for economic activities and capital provision on per capita GRDP. To examine the effect of the consumptive ZIS distribution on per capita GRDP through the ZIS distribution for economic activities and capital provision.

\section{LITERATURE REVIEW}

Islamic economics has the goal of personal and collective benefit so that in collecting property for personal needs as an individual it aims to support the implementation of worship to Allah SWT and fulfillment of common needs which are usually called social needs in order to maintain worship with others. This fact shows that in the concept of Islamic economics, increasing income is not the ultimate goal in economics. At the macro level, there is collective benefit, namely togetherness in terms of distribution of wealth to others, not adding personal property without thinking of others because this wealth must be enjoyed collectively. In other words, in order to achieve the ultimate goal of Islamic economics in the form of falah one must go through one of its instruments, namely collective welfare. Islamic economics views the gap as sunnatullah, there are those who are lucky in material terms and some are less fortunate. In other words, these differences must be maintained so that relations between groups can achieve prosperity together. Keeping this relationship from widened where the less fortunate feel slumped and the lucky ones become arrogant, Islamic economics brings them closer to the mechanism of distribution of assets in according with sharia guidance.

The objectives of income distribution in Islamic economics can be grouped as follows; (1) the purpose of da'wah, (2) educational purposes, (3) social goals, and

\footnotetext{
${ }^{6}$ Federico Cingano, “Trends in Income Inequality and Its Impact on Economic Growth,” OECD Social, Employment, and Migration Working Papers, no. 163 (2014): 0_1,5-59, https://doi.org/http://dx.doi.org/10.1787/5jxrjncwxv6j-en.

${ }^{7}$ Cingano.
} 
(4) economic goals ${ }^{8}$. These goals reinforce that the main instrument in the distribution of income in an Islamic economy is alms, in this case in the form of zakat. The essence of distribution in Islam is how to balance the wealth between the excess and the lacking by using the instruments of alms that are zakat, donation and alms. According to Indri, income distribution has the following objectives; (1) Ensuring the fulfillment of basic community needs; (2) Reducing the inequality of income and wealth in society; and (3) To develop property from two sides, namely spiritual and economic ${ }^{9}$.

Wahbah Az-Zuhaili concluded that zakat in the definition of the fuqaha is used for the act of giving zakat itself. That is, giving mandatory rights to property. Zakat in urf fuqaha is also used to understand a certain part of the property that has been determined by Allah as the right of the poor. Zakat is called shadaqah because it shows the honesty of servants in worship and obedience to Allah ${ }^{10}$.

According to law number 23 of 2011 concerning zakat management, zakat is defined as assets that must be issued by a Muslim or business entity to be given to those who are entitled to receive it in accordance with Islamic law. Infaq is property issued by a person or business entity outside of zakat for the public benefit. Alms are assets or non-wealth issued by a person or business entity outside of zakat for the general benefit.

There are two ways to distribute zakat, namely consumptive distribution and productive distribution. ${ }^{11}$ This study uses the distribution of zakat, infaq and total alms and the distribution of productive zakat. The total distribution is the total value of the ZIS distribution based on the reports of zakat managers which are generally and traditionally identified as a form of consumptive distribution. Productive distribution is part of the total distribution allocated for economic activities and capital provision in rupiah units.

Besides that, zakat is a form of worship that has multiple dimensions, transcendental and horizontal values. Therefore, zakat has many meanings for human life, especially for followers of Islam. Zakat has many wisdoms, both related to Allah SWT. as well as social relations among humans, among others: 1) Safeguard and fortify property from the sight of people, the reach of the hands of sinners and criminals; 2) Help the needy people and people in need; 3) Purifying oneself from the disease of miser and hunks, accustom the believers to give and be generous, so that they are not only limited to zakat; 4) Require to be grateful for the blessings of wealth ${ }^{12}$.

One of the wisdom (significance) of zakat, namely the significance of ijtimaiyyah. The concept of wisdom shows that zakat as a means of fulfilling the needs of the poor, encourages and promotes the existence of the poor, brings closer relationships between the poor and the rich, encourages economic growth, and Pers, 2015).

${ }^{8}$ Rozalinda, Ekonomi Islam : Teori Dan Aplikasinya Pada Aktivitas Ekonomi, cet 2 (Jakarta: Rajawali

${ }^{9}$ havis aravik, Sejarah Pemikiran Ekonomi Islam Komtemporer (Depok: Kencana, 2017).

${ }^{10}$ Az-Zuhaili, Fiqib Islam Wa Adillatubu.

11 Mubasirun Mubasirun, "Distribusi Zakat Dan Pemberdayaan Ekonomi Umat,” Inferensi 7, no. 2 (2013): 493, https://doi.org/10.18326/infsl3.v7i2.493-512.

12 Az-Zuhaili, Fiqib Islam Wa Adillatubu. 
expands the circulation of assets. ${ }^{13}$ Sugeng Priyono stated that the effect of zakat on the growth in consumption rate is a direct effect, while the asset effect is indirect. The growth of the muzakki's assets will increase the total zakat paid and cause the zakat funds distributed to the mustahik to increase, ultimately increasing the ability to consume in the aggregate. ${ }^{14}$ Optimizing the role of zakat can overcome poverty, income inequality and unemployment problems. Zakat that is optimized reduces the number of poverty, reduces the ratio of inequality and the number of unemployed which in itself will significantly increase the per capita income. There are two ways to distribute zakat, namely consumptive distribution and productive distribution. ${ }^{15}$ This study uses the distribution of zakat, infaq and alms total and the distribution of productive zakat. The total distribution is the total value of the ZIS distribution based on the zakat management report which is generally and traditionally identified as a form of consumptive distribution. Productive distribution is part of the total distribution allocated for economic activities and capital providing in rupiah units.

The consumptive ZIS distribution in general encourages the level of consumption for zakat recipients and also an income generator so that it can free them from poor areas. The distribution of consumptive ZIS can raise the degree of the poor, the zakat received can also bring the recipient and the giver of zakat closer to the aspect of property ownership because of the transfer of some assets from the rich to the poor in real terms. Changing the status of poor people to being able and close to zakat payers will automatically result in increased income. The increase as a result of the circulation of assets valued at zakat, which if not distributed will result in the assets not moving anddoes not add value.

ZIS distribution for economic activities and provision of capital (productive zakat) in the concept of Islamic economics can increase income from the investment side. This form of distribution based on the results of previous studies shows that it is better to reduce the poverty rate significantly, as well as the faster the inequality ratio is reduced. This happens because by distributing zakat for economic activities it can produce a wider effect, where productive zakat can encourage production. The rotation of assets is getting longer so that more and more people get the benefits. Productive zakat also brings the giver and recipient of zakat closer together, because it could be that the giver of zakat becomes the supervisor for the recipient of zakat in terms of investment management. The distribution of ZIS for economic activities and capital providing is more effective to reducing the number of poor people, reducing the gap ratio which in turn has a greater potential to encourage an increase in GDP per capita.

The main objective of economic development is to build capital equipment on a scale sufficient to increase productivity in agriculture, mining, plantation, industry and other fields, capital is also needed for the construction of schools, hospitals, roads and railways as well as other infrastructure. In short, economic development is the creation of social and economic overhead capital. This is only possible if the rate of capital formation in the country is fast enough, that is, only a small share

\footnotetext{
13 Az-Zuhaili.

14 Sugeng Priyono, "Zakat Sebagai Instrumen Dalam Kebijakan Fiskal," Al Mashlahah Jurnal Hukum Dan Pranata Sosial Islam, 2017, 125-42.

${ }^{15}$ Mubasirun, "Distribusi Zakat Dan Pemberdayaan Ekonomi Umat.”
} 
of the income or output in society is used for consumption and the rest is saved and invested in capital equipment. As shown by Lewis, a central problem in economic development theory is the process of increasing national saving and investment. Investments in capital equipment not only increase production but also employment opportunities, the formation of capital results in technical advances that support the achievement of a large-scale production economy and increase specialization. Capital formation provides machinery, tools and equipment for an increasing workforce. In essence, capital formation has a positive effect on job opport unities. ${ }^{16}$

Economic development is the process of increasing real income per capita which causes changes in the form of an increase in living standards over a long period of time. The form of the development result in question is the annual Gross Regional Domestic Product (PDRB). In this context, there are two product limitations, namely; domestic products and regional products. Domestic products according to BPS are all service goods as a result of economic activities operating in the domestic area, regardless of whether the production factor originates from or is owned by residents of that area,which is the domestic product of the region concerned. Furthermore, regional products are domestic products plus income from production factors received from outside the region minus income from production factors paid out of the region / country. So the Gross Regional Domestic Product (PDRB) is all goods and services as a result of economic activities operating in the domestic area plus the difference between production factor income received and paid from and outside the region / country.

The discussion of zakat in macroeconomics cannot be separated from the main function of zakat as the main variable for increasing the demand side in the economic system. Demand can increase consumption in the aggregate to encourage economic growth. According to Rozalinda, the existence of zakat can shift the demand curve for mustahik through the increasing aggregate demand, as a result of the strengthening purchasing power which is driven by the distribution of zakat. Furthermore, in the short term it can increase prices, resulting in increased producer acceptance. In this case, information on price increases is known to all market participants, which will result in new players in the market. In other words, this response can increase production resulting in increased supply. Therefore, the price in the market will correct itself and produce a new equilibrium in the market. ${ }^{17}$

\section{METHODS}

The research method used is quantitative with an explanatory approach. The study population was the districts and cities in South Sulawesi. The data used are; consumptive ZIS distribution, ZIS distribution for economic activity and provision of capital and GDP per capita according to business fields and constant prices in the form of published documents. The sample used was 105 in the form of data panels consisting of 21 districts and cities using 5 years of documentation data (2015-2019). Data processing and analysis techniques use panel data regression statistical tests and path analysis using Eviews program data processing. The analysis method used is the

\footnotetext{
16 Rudifachru, "Pembentukan Modal Dalam Pembangunan,” 2019.

${ }^{17}$ Rozalinda, Ekonomi Islam : Teori Dan Aplikasinya Pada Aktivitas Ekonomi.
} 
panel data regression model, while the model used for the panel data equation is as follows;

$$
\mathrm{Y}_{i t}=\alpha+\beta_{1} \mathrm{X}_{1 i t}+\beta_{2} \mathrm{X}_{2 i t}+\ldots .+\beta_{n} \mathrm{X}_{n i t}+\varepsilon_{i t}
$$

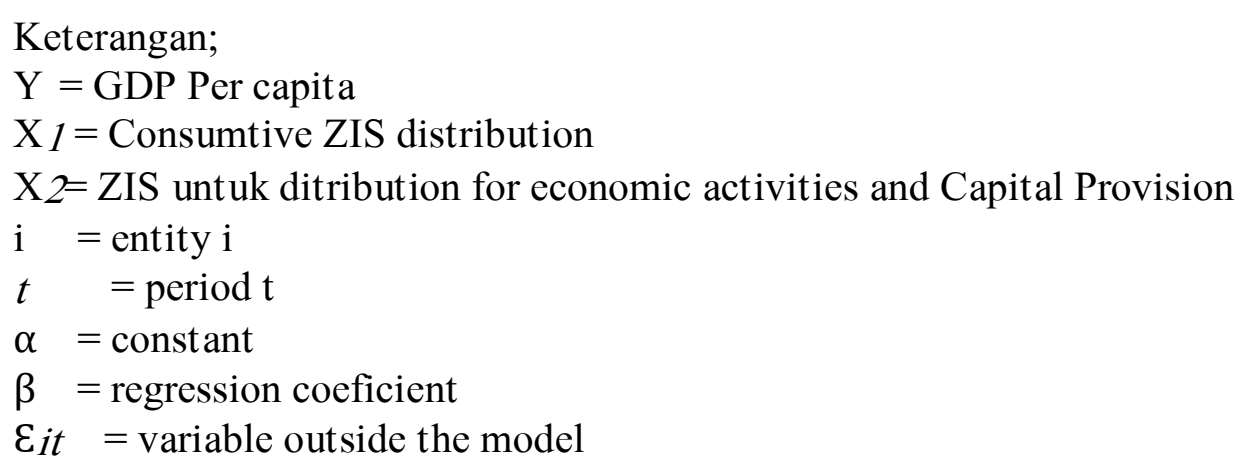

\section{DISCUSSION}

\section{A. Variabel Description;}

Based on the results of data processing for variable descriptive analysis as follows;

Table 1: Variable Descriptions

\begin{tabular}{|c|c|c|c|c|c|}
\hline \multirow{2}{*}{ Variable } & \multicolumn{5}{|c|}{ Deskripsi } \\
\cline { 2 - 6 } & Maximum & Minimum & Mean & Median & Standar Deviation \\
\hline DZISK & $17.856 .307 .092,00$ & $14.700 .000,00$ & $2.652 .944 .326,18$ & $1.150 .276 .283,50$ & 3.241 .317 .239 \\
\hline DZISEM & $2.871 .482 .000,00$ & $735.000,00$ & $263.360 .629,07$ & $77.276 .611,00$ & $493.741 .780,30$ \\
\hline PDRB & $116.874 .792,26$ & $19.688 .454,30$ & $41.858 .364,86$ & $38.648 .682,65$ & $16.718 .942,56$ \\
\hline
\end{tabular}

Source: Processed data

Based on the research variable description table, it shows that the maximum value of the consumptive ZIS distribution variable (DZISK) is IDR 17,856,307,092.00. This value shows the highest consumptive ZIS distribution value from the sample. Meanwhile, the minimum value of the sample is IDR 14,700,000.00. When it compared between the minimum and maximum values, it gives an overview of the data range and high data variance. However, the average consumptive ZIS distribution value of the sample is IDR 2,652,944,326.18. This means that the sample data between the mean value and the maximum value have a higher range and data variation when compared to the range and variance of the data against the minimum value. While the median value shows a value of IDR 1,150,276,283.50. This means that $50 \%$ of the sample of the consumptive ZIS distribution is less than IDR $1,150,276,283.50$ and $50 \%$ of the sample data is greater than IDR $1,150,276,283.50$. This value is smaller than the average value. This means that the distribution of consumptive ZIS districts / cities in South Sulawesi Province is more than the average value. This is evidenced by the high standard deviation value obtained, namely 324.1317.239. This means that each sample has a deviation from the mean value of 324.1317.239. When it compared the standard deviation value with the mean value of the sample data, it can be seen that the standard deviation value is 
greater than the mean value of the sample of data, meaning that the sample data distribution of the consumptive ZIS distribution variable has high variance.

The ZIS distribution variable for economic activities and capital providing shows that the maximum value obtained is IDR 2,871,482,000.00. While the lowest value is IDR 735.000.00 based on the minimum variable value. These condition resulted in the ZIS distribution average for economic activities and capital provision was still very low with a value of IDR 263,360,629.07. When compared with the average consumptive ZIS distribution variable, the value of the ZIS distribution for economic activities is only about $10 \%$ of the value of the consumptive ZIS distribution. If seen from the median value, it shows a value of IDR. 77,276,611.00. This means that $50 \%$ of the sample data is less than IDR $77,276,611.00$, and $50 \%$ of the sample data is greater than IDR 77,276,611.00. This means that the sample data of the ZIS distribution for economic activities and capital provision are not normally distributed. This is supported by the standard deviation value of 493,741,780.30. This means that the average value of the sample keeps from the average value of the sample of 493,741,780.30.

Based on the variable description table in table 1, the sample data obtained from the variable Gross Regional Domestic Product per capita shows a maximum value of IDR. 116,874,792.26. The minimum sample data from the per capita GRDP variable is IDR $19,688,454.30$, meaning that the lowest GDP per capita of South Sulawesi Province is IDR 19,688,454.30. Meanwhile, the average value of the GDP per capita variable for five years was IDR 41,858,364.86. This means that the per capita GRDP of South Sulawesi Province during 2015-2019 averaged IDR $41,858,364.86$. When compared to the mean value with the maximum and minimum value of the sample data from the per capita GRDP variable, it can be seen that the distance is quite large, meaning that the sample data may not be normally distributed. This is supported by the high standard deviation value of $16,718,942.56$, meaning that each sample has an average storage of 16,718,942.56 samples.

\section{B. Model Selection and Testing}

This study uses three regression equation models to analyze the influence between variables. Based on the results of model selection and testing using E-Views 9, the following model test results are obtained:

Table 2: Determinant ang F Test Results

\begin{tabular}{|c|c|c|c|c|c|c|}
\hline No. & The Effect of & $\begin{array}{c}\text { Ajustted R- } \\
\text { Squared }\end{array}$ & $\begin{array}{c}\text { F- } \\
\text { Statistical }\end{array}$ & $\begin{array}{c}\text { Probabilit } \\
\text { y }\end{array}$ & Model & Conclusion \\
\hline 1 & DZISK $\rightarrow$ & 0,71007 & 252,262 & 0,000 & REM & Received \\
\hline 2 & DZISK $\rightarrow$ PDRB & 0,89804 & 34,812 & 0,000 & FEM & Received \\
\hline 3 & DZISEM $\rightarrow$ PDRB & 0,88922 & 31,725 & 0,000 & FEM & Received \\
\hline
\end{tabular}

Source: Processed from Output E-Views 9

Based on the test results in the table above, it is obtained 2 fixed effect models and 1 random effect. From the results of the determinant test using the ajustted $\mathrm{R}$ - Squared value and the F test for the three models used are described as follows: 1) The effect of the consumptive ZIS distribution on the ZIS distribution for economic activity and capital provision obtained ajustted R-Squared value of 0.71007 or $71 \%$, 
it shows that $71 \%$ of the ZIS distribution for economic activities and capital provision is represented by the consumptive ZIS distribution. The remaining $19 \%$ is determined by other factors outside of those studied. Based on the F test, the F-statistic value was obtained 252,262 with a probability of $0,000<0.05$. That is, simultaneously the consumptive ZIS distribution variable affects the ZIS distribution for economic activities and the provision of capital; 2) The effect of consumptive ZIS distribution on GRDP per capita obtained ajustted R-Squared value of 0.89804 or $89.9 \%$, this indicates that $89.9 \%$ of GDP per capita is described by the consumptive ZIS distribution. The remaining $10.1 \%$ was determined by other factors outside of the study. Based on the F test, the F-statistic value is 34.812 with a probability of 0.000 $<0.05$. That is, simultaneously the consumptive ZIS distribution variable affects the GDP per capita; and 3) The effect of ZIS distribution for economic activities and capital provision on GDP per capita obtained ajustted R-Squared value of 0.88922 or $88.92 \%$, this indicates that $88.92 \%$ of GDP per capita is described by the ZIS distribution for economic activities and capital provision. . The remaining $11.08 \%$ was determined by other factors outside of the study. Based on the F test, the F-statistic value was obtained 31,725 with a probability of $0,000<0.05$. That is, simultaneously the consumptive ZIS distribution variable affects the GDP per capita.

The magnitude of the influence of the independent variable on the dependent variables is used the model test output with the test. Based on the results of the feasibility test of the model with eviews for the three selected influence models, the following results were obtained;

Table 3: Results of the $t$ test

\begin{tabular}{|c|c|c|c|c|c|c|c|}
\hline $\begin{array}{c}\text { No } \\
\cdot\end{array}$ & $\begin{array}{c}\text { The } \\
\text { Influence of }\end{array}$ & Constant & Coefficient & $\begin{array}{c}\mathrm{t}- \\
\text { Statistic }\end{array}$ & Probability & $\begin{array}{c}\text { Form of } \\
\text { Influence }\end{array}$ & Conclusion \\
\hline 1 & DZISK $\rightarrow$ & $18,387,205$ & 0,0951 & 15,794 & 0,0000 & Positive & Significantly \\
\hline 2 & DZISK $\rightarrow$ & $38,746,536$ & $5,93 \mathrm{E}-04$ & 3,589 & 0,0006 & Positive & Significantly \\
\hline 3 & $\begin{array}{c}\text { DZISEM } \rightarrow \\
\text { PDRB }\end{array}$ & $40,892,269$ & $1,87 \mathrm{E}-03$ & 2,291 & 0,0245 & Positive & Significantly \\
\hline
\end{tabular}

Source: Processed from Output E-Views 9

Based on the test results in the table above, it is known that: 1) The consumptive ZIS distribution has a significant positive effect on the ZIS distribution for economic activities and capital provision. From this model, it shows a constant value of $18,387,205$, which means that if the consumptive ZIS distribution is zero (0) or constant, the ZIS distribution for economic activities and capital provision is IDR 18,387,205.00. Meanwhile, the coefficient value of the consumptive ZIS distribution variable is 0.0951 , this indicates that every change of one (1) recommendation for the consumptive ZIS distribution variable results in the ZIS distribution variable for economic activity and capital provision changing by 0.0951 ; 2) The consumptive ZIS distribution has a significant positive effect on GDP per capita. The model shows a constant value of 38,746,536, meaning that if the ZIS distribution is consumptive is zero (0) or constant, then the GDP per capita is IDR 38,746,536.00. Meanwhile, the coefficient value of the consumptive ZIS distribution variable is 0.000593 (5.93E-04), this indicates that every change of one (1) recommendation for the consumptive ZIS distribution variable causes the per capita GRDP variable to 
change by 0.000593 ; 3) ZIS distribution for economic activities and provision of capital have a significant positive effect on GDP per capita. The model shows a constant value of $40,892,269$, meaning that if the ZIS distribution for economic activities and capital provision is zero (0) or constant, then the GDP per capita is IDR 40,892,269.00. Meanwhile, the coefficient value of the ZIS distribution variable for economic activities and capital provision is 0.00187 (1.87E-03), this indicates that every change of one (1) ZIS distribution variable recommendation for economic activity and capital provision results in the per capita GRDP variable. changed by 0.00187. The influence model can be summarized in the following figure;

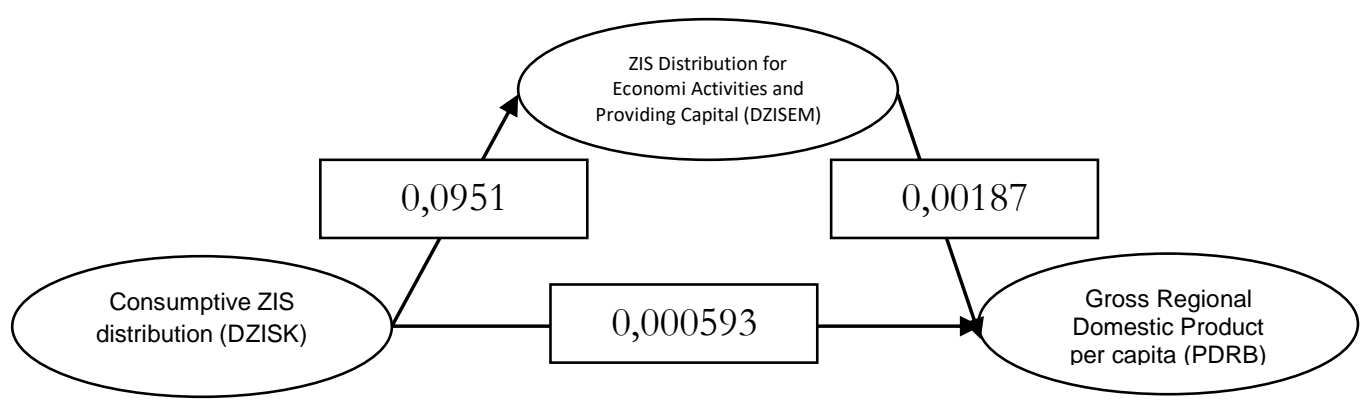

1. The Effect of Consumptive ZIS Distribution on ZIS Distribution for Economic Activities and Capital Giving

Based on the results of the model test, it is proven that the consumptive ZIS distribution has a significant positive effect on the ZIS distribution for economic activities and the capital providing. The size of the ZIS distribution for economic activities and the capital providing depends on the size of the zakat distributed. The size of the zakat that is distributed really depends on the amount of zakat collected. Therefore, it needs to be strengthening for zakat collectors so that the distribution of zakat can be maximized. If, the results of collecting zakat can be maximized, then the distribution can be maximized.

These findings support Siti Zalikha's findings which reveal that the productive distribution of zakat is permitted with the intention of improving the economic life of the mustahik (2016:304-319). Productive distribution of zakat is permitted as long as the purpose of the distribution is for the mustahik. This means that the distribution of zakat in a productive form can be carried out as long as the recipient is the right mustahik. With the productive zakat, it is hoped that it will be more capable of releasing mustahik from poverty and inequality. The greater the allocation of zakat distribution for productive purposes will provide greater opportunities in solving the problem of poverty and inequality which in turn will encourage the growth of zakat collection.

In line with the findings of Khalifah Muhammad Ali, Nydia Novira Amalia and Salahuddin El Ayyubi revealed that consumptive and productive zakat distribution has been proven to increase welfare while reducing mustahik poverty. However, productive zakat is more capable of improving mustahik welfare than consumptive zakat (2016:19-32). Because zakat is productively better able to increase the welfare of mustahik, the higher the allocation for zakat productively, the greater the potential for increasing welfare. So that the higher the zakat collection, the greater the zakat allocation for economic activities and the provision of capital. 
2. The Effect of Consumptive ZIS Distribution on Gross Regional Domestic Product Per Capita

Based on the results of hypothesis testing on the selected model, it is known that the consumptive ZIS distribution has a significant positive effect on the Gross Regional Demographic Product per capita. This means that if there is an increase in the value of the consumptive ZIS distribution, it will encourage the growth of Gross Regional Domestic Product (GRDP) per capita. Even so, the value is not that big which is indicated by the low coefficient value which is still small. This condition occurs because the ZIS revenue is still low so that the distribution is also limited according to the results of the collection. In line with what Adel Sarea who found that when people pay zakat the economic growth rate will be higher. Likewise with what was found by Abdul Haris Romdhoni who found that zakat is able to encourage economic growth with the case study LAZ An-Naafi 'Boyolali (2017:4351). Similar to the findings of Rachmasari Anggraini, Dr. Adel Serea, Irfan Sauqi Beik with Laily Dwi Arsyianti, Bayu Taufiq Possumah, as well as research results from M. Anton Athoillah that zakat can boost economic growth. Muhammad Azam, Nasir Iqbal and Muhammad Tayyab found that zakat significantly contributes to economic growth in Pakistan.

This finding is also in line with the concept of economic distribution that at the macro level can encourage economic growth from two sides, namely from the demand side (consumption) and from the supply side (investment). When zakat is distributed for consumption, such as zakat fitrah, it will affect income through consumption. Zakat that is distributed for consumption will result in a shift in funds from excess to less, so that those who are lacking can increase their consumption better. Additional consumption due to zakat funds results in additional demand for goods and services for consumption. Likewise, from the supply side, if the zakat is distributed to economic activities and the provision of capital will result in additional production for producers which in turn will increase the supply of goods and services. So that it will create a new balance in the market. This shift is expected to increase income economically.

It has actually been explained in the Al-Qur'an surah Al-Baqarah verse 261 that the treasure that is invested in the way of Allah is like a seed that grows seven ears, on each one hundred seeds. By means of a living in the way of Allah, the assets used will be multiplied. Even so, in various interpretations it is stated that the parable is for merit, but in various cases it shows that it has proved successful in increasing income for both the giver and the recipient of the income. Likewise in Surah AtTaubah verse 60 , it explains that zakat must be evenly distributed to provide for the poor and the zakat management. This means that zakat can really be used as an instrument for increasing income (economic growth), equitable distribution of income to meet the needs of all parties (tafsirq.com, 2020).

This is in line with Habib Ahmed's findings that macroeconomic policies and zakat in Bangladesh have an important role in reducing poverty and have a more significant effect when the percentage of zakat distribution is used for productive purposes (Ahmed, 2004:84-111). In this study we tried to see the effect of zakat on GDP per capita through poverty and inequality variables. This is done with the assumption that the Islamic economy with the zakat instrument has the main 
goal, namely equity, while increasing welfare with income as the next target. Therefore, in the study of economic development using zakat as an instrument, poverty and inequality should be targeted. Therefore, with the reduction of the poor and the smaller the distance between the excess and the less so that prosperity is achieved. This is also in line with the findings of Khairina Tambunan, Isnaini Harahap, and Marliyah, which states that zakat has a significant effect on the economy with the GDP indicator (Tambunan, 2019:249-264. Zakat can affect economic growth through the consumption side and it is short-term. Therefore, zakat that is distributed for consumption will have a direct effect on the consumption of zakat recipients by increasing their consumption. This consumption automatically becomes an addition to income in the economic equation model, in this case economic output.

3. Effect of ZIS Distribution for Economic Activities and Capital Provision on Gross Regional Domestic Product Per Capita

The direct effect of the ZIS distribution for economic activities and capital providing has a significant positive effect on the Gross Regional Domestic Product (GRDP) per capita. These findings are proven from the results of hypothesis testing on the selected model. The influence of the ZIS distribution on the Gross Regional Domestic Product (PDRB) per capita simultaneously and partially. This finding is also reinforced by information on zakat managers in South Sulawesi Province, both from BAZNAS and from LAZ. They admit that the distribution of ZIS for economic activities and provision of capital is more effective in increasing mustahik income and is better able to provide support for the growth of GDP per capita. Therefore, the collection of zakat has not been maximized so that the value of zakat that can be distributed for economic activities and providing capital is still small.

These findings support the findings of Abdul Haris Romdhoni who found that there was a positive influence between the utilization of the productive zakat program on mustahiq's income (2017:41-51). This is also in line with the findings of Muh. Amri Cahyadi stated that productive zakat has a significant positive effect on welfare (2016). The increase in income was caused by the utilization of productive zakat. The development of income and fulfillment of mustahik needs can be seen after receiving assistance from zakat utilization programs which can also be used for business capital. ZIS distribution for productive activities (utilization of zakat) is more able to give a boost to the economy because it has a wider impact. Increased welfare due to the distribution of productive zakat which encourages the growth of micro-businesses which results in increased production. Thus, an increase in production results in an increase in the supply of goods and services so that the market becomes more competitive. Thus, competitive prices coupled with an increase in income will encourage an increase in consumption which in turn will increase income.

The results of this study are also in line with those expressed by Hidayat Aji Pambudi that productive zakat, supervision and assistance have a positive effect on income, consumption, savings and mustahik incomes. ${ }^{18}$ Productive zakat encourages an increase in income and can also encourage consumption, savings and mustahik infaq. The increase in mustahik's income is of course the first choice of additional

18 Aji Hidayat Pambudi, "Peran Zakat Produktif Dalam Pemberdayaan Masyarakat Miskin," Fokus Bisnis 12, no. 2 (2013): 70-80. 
income to be used to maximize the fulfillment of their needs which will encourage consumption. If there is still an excess of additional income, the second option is savings and donations. In Islam, infak is also categorized as savings for the afterlife. Of course, with an increase in income, consumption, savings and income can increase aggregate income when the program is implemented evenly for Muslim communities.

These findings strengthen Tika Widiastuti's opinion that the utilization of productive zakat is a model capable of increasing mustahiq income. ${ }^{19}$ Utilization of productive zakat in the form of financial assistance to increase business capital for those who have businesses and skills will encourage increased productivity. By becoming more productive, they can increase their production output which will increase their income from the additional capital received. This additional benefit if it occurs as a whole will encourage economic growth which can increase per capita income.

This is also in line with Nasrullah's findings which state that the giving of productive zakat has a significant impact on supporting the prosperity of society. Productive zakat in the form of providing business capital loans based on qard alhasan can motivate the recipient's business properly and maximally. ${ }^{20}$ The distribution of zakat is given to those who actually do not include the recipients of zakat so that it takes the form of loans. However, this has proven to be able to increase the income of loan recipients from zakat. Which in the end will Give birth to new donors of zakat, or even be able to create new jobs and employ people who are entitled to receive zakat to be the beneficiaries of the zakat used.

It is also in line with the findings of Khalifah Muhammad Ali, Nydia Novira Amalia and Salahuddin El Ayyubi who stated that the consumptive and productive zakat distribution can improve welfare while reducing poverty. However, productive zakat is more capable of improving mustahik welfare than consumptive zakat. ${ }^{21}$ The distribution of productive zakat can help mustahik get out of the poor quadrant category into the prosperous quadrant because of the increase in income obtained from utilizing productive zakat. Productive zakat has more potential to reduce the poor than consumptive zakat because productive zakat can create more effects than consumptive zakat. Economically, the additional consumption resulting from consumptive zakat does not actually increase income because it only transfers wealth from excess to less. The effect is only from the utility margin which is created higher when moving to the poor. Meanwhile, productive zakat can increase the production of goods and services so that there is additional output which is additional income. Not to mention if the additional volume of production generated requires additional labor or can even create new businesses.

19 Tika Widiastuti and Suherman Rosyidi, "Model Pendayagunaan Zakat Produktif Oleh Lembaga Zakat Dalam Meningkatkan Pendapatan Mustahiq," Jurnal Ekonomi Dan Bisnis Islam 1, no. 1 (2015): 89-102.

${ }^{20}$ Nasrullah Nasrullah, "Regulasi Zakat Dan Penerapan Zakat Produktif Sebagai Penunjang Pemberdayaan Masyarakat (Studi Kasus Pada Baitul Mal Kabupaten Aceh Utara)," Inferensi 7, no. 1 (2015): 1, https://doi.org/10.18326/infsl3.v9i1.1-24.

${ }^{21}$ Khalifah Muhamad Ali, Nydia Novira Amalia, and Salahuddin El Ayyubi, "Perbandingan Zakat Produktif Dan Zakat Konsumtif Dalam Meningkatkan Kesejahteraan Mustahik The Comparative Study Between Productive and Consumptive Based Zakat 1 Pendahuluan 2 Tinjauan Pustaka," Jurnal Al-Muzara'ah 4, no. 1 (2016): 19-32. 
This has been disclosed in the Al-Qur'an Surat Al-Baqarah Verses 261262 , a piece of the translation "... a treasure that is invested in the way of Allah is like a seed that grows seven ears, on each one a hundred seeds ... ". This means that if the property is distributed in Allah's way, in this case in the form of zakat, donations and alms, it will have multiple effects in the economy. And this verse is very appropriate if it is used to link the distribution of zakat for economic activities and the capital providing (productive zakat), then this verse can be realized in the economy. Because giving zakat in the form of productive zakat can give birth to many benefits compared to if it is only given for consumption purposes.

4. The Effect of Consumptive ZIS Distribution on PDRB Per Capita through ZIS Distribution for Economic Activities and Capital Giving

Based on the findings, the effect of the Consumptive ZIS distribution is proven to have a significant positive effect on the Gross Regional Domestic Product per capita through the ZIS distribution for economic activities and provision of capital. This means that the consumptive ZIS distribution can increase the Gross Regional Domestic Product per capita by increasing the ZIS distribution for economic activities and providing capital. These findings indicate that the higher the value of the ZIS distribution allocation for economic activities and the provision of capital, the greater the potential for stimulating economic growth, in this case an increase in the Gross Regional Domestic Product per capita. This finding proves the concept of the wisdom of zakat from Wahbah Az-Zuhaili, one of which is to help needy people and people who are in need and free from poverty. Zakat can guide their hands to start work and activities if they are capable of this. Zakat can also help them to lead to noble life situations if they are weak. Zakat protects people from indigent diseases, protects people from disability and weakness. Community groups are responsible for the security of needy people and their needs. ${ }^{22}$ From one of the explanations, this wisdom guides their hands to start work and activities if they are able. This means that zakat has the aim of turning the poor into productive according to his abilities. If the poor turn to be productive, it automatically contributes to the output of development so that it contributes to aggregate income. This also proves Jinghan's theory that one of the causes of stunting to economic growth is the limited access of the poor to capital and the need for social capital to be developed. With the distribution of ZIS for economic activities and provision of capital is one of the potentials that provide opportunities for access to capital for the poor as well as social capital.

The consumptive ZIS distribution affects the increase in GDP per capita by directly increasing the consumption of the poor. This is in line with the concept of final spending developed by Sukarno Wibowo and Dedi Supriadi, which includes zakat as a determinant of Islamic consumption. ${ }^{23}$ This means that zakat will encourage consumption growth with the assumption that the funds from zakat are excess funds for unused mustahik. When these funds are used to fulfill the obligation of zakat, plus donations and alms in addition to changing the assets into benefits for the recipient of zakat. For zakat recipients, of course, the priority is to fulfill their basic needs in terms

\footnotetext{
22 Az-Zuhaili, Fiqib Islam Wa Adillatubu.

${ }^{23}$ Sukarno. Dedi Supriadi Wibowo, Ekonomi Mikro Islam (Bandung: CV. Pustaka Setia, 2017).
} 
of consumption. With the addition of zakat used for consumption in theory it adds to aggregate output. Likewise in Fahim Khan's view of the consumption and saving function by including zakat as a consumption enhancer and a substitute for saving in other forms. Likewise with Iqbal in his notes 'Zakat, Moderation, and Aggregate Consumption in an Islamic Economy' by including consumption in Allah's way, in this case zakat. ${ }^{24}$ Zakat is a substitute for savings for muzakki, meaning that at the expense of saving for the world, it is replaced by savings in the afterlife in the form of zakat obligations plus infaq and alms as an addition to the sunnah. Meanwhile, the distribution of ZIS for economic activities and provision of capital affects the increase in GDP per capita through investment and increased production. As in the investment concept by Metwally which includes zakat as a function of investment. ${ }^{25}$ With the distribution of ZIS, it encourages an increase in demand for consumer goods as well as capital goods. This means that the consumptive distribution of ZIS through economic activities and provision of capital can be an alternative source of capital for the poor. With zakat, it can overcome the problem of difficult access to capital for the poor. Access to ZIS is only for the poor without conditions. With this access, it helps the poor to meet their basic needs in the form of consumption and can also free them from poverty by starting access to capital from the ZIS distribution as expected by Nurkse.

This is also in line with the findings of Rachmasari Anggaraini, Ryval Ababil and Tika Widiastitu who revealed that ZIS funds had a positive effect on economic growth in Indonesia for the 2011-2015 period. Which is because the higher distribution of ZIS funds indicates the higher the level of economic growth of the people in Indonesia. ${ }^{26}$ In addition, ZIS funds and inflation have a simultaneous or simultaneous effect on economic growth in Indonesia. This shows that the ZIS distribution when juxtaposed with other variables in this case inflation will be able to have a simultaneous effect on economic growth. Likewise with the findings of Abdul Haris Romdhoni that the productive zakat utilization program has a significant effect on increasing mustahik income through the zakat fund program. ${ }^{27}$ These findings also prove what was expressed by Adam Smith that the accumulation of capital is an absolute condition for economic development. According to Adam Smith, the fastest way is to invest in such a way that it can provide the greatest income to the entire population. This is in line with the concept of zakat distribution through economic activities and provision of capital (productive zakat). Productive zakat is a form of capital accumulation in the concept of Islamic economics. this concept could be faster and more effective than what was expressed by Adam Smith. The distribution of zakat is faster because the existing capital can go directly to the needy and right on

${ }^{24}$ Muhammad Akram, "Munich Personal RePEc Archive Theory of Consumer Behavior : An Islamic Perspective,” MPRA Paper, no. 104208 (2020).

25 Akram.

${ }^{26}$ Rachmasari Anggraini, Ryval Ababil, and Tika Widiastuti, "Pengaruh Penyaluran Dana ZIS Dan Tingkat Inflasi Terhadap Pertumbuhan Ekonomi Indonesia Periode 2011-2015,” FALAH: Jurnal Ekonomi Syariah 3, no. 2 (2018): 1, https://doi.org/10.22219/jes.v3i2.7231.

${ }^{27}$ Sundari Sundari, "Zakat Dalam Mendorong Pertumbuhan Ekonomi Dan Pengentasan Kemiskinan," Al-’ Adalah : Jurnal Syariah Dan Hukum Islam 3, no. 1 (2018): 23-35, https://doi.org/10.31538/adlh.v3i1.403. 
target. Meanwhile, the concept that Adam Smith offers is capital fertilization through an increase in the savings that it contributes to being very difficult to reach the poor.

ZIS distribution affects GDP per capita through economic activities and capital providing. The increase in PDRB per capita can be managed using zakat instruments through economic activities and capital providing. PDRB per capita increases in the future can be achieved by increasing the value of the distribution of zakat through increasing the distribution of zakat for economic activities and capital providing. Through economic activities and capital expenditures, the distribution of zakat is effective in encouraging the growth of GDP per capita from two sides, namely from the consumption side and from the investment side (production).

\section{CONCLUTION}

Increasing the value of the consumptive ZIS distribution can increase the value of GRDP per capita. Zakat became a source of capital in economic development which is one of the problems faced by regions and countries in achieving prosperity. Zakat as an instrument of distribution in the Islamic economy has been proven to promote economic growth.

Increasing the value of the ZIS distribution for economic activities and providing capital increases the GRDP per capita. Zakat in the form of had kifayah, productive zakat or zakat for economic activities and capital providing is a source of investment that is free from the practice of usury with very easy access for the poor because there is no guarantee. Investment growth as a result of capital accumulation from zakat, which dominantly grows from the side of the poor. Increased free capital for the poor can increase income. The ZIS distribution for economic activities and the capital providing ultimately helps to grow in aggregate per capita income.

Increasing the consumptive ZIS distribution can increase the GDP per capita by increasing the ZIS distribution for economic activities and providing capital, reducing the poverty rate, and reducing the gap ratio. One of the lessons of zakat is to meet the basic needs of the poor and free them from poverty. The concept of distribution in Islam for fulfilling basic needs is more important than income growth, the fulfillment of the basic needs of the poor by itself increases aggregate income.

\section{REFERENCES}

Akram, Muhammad. "Munich Personal RePEc Archive Theory of Consumer Behavior : An Islamic Perspective." MPRA Paper, no. 104208 (2020).

Ali, Khalifah Muhamad, Nydia Novira Amalia, and Salahuddin El Ayyubi. "Perbandingan Zakat Produktif Dan Zakat Konsumtif Dalam Meningkatkan Kesejahteraan Mustahik The Comparative Study Between Productive and 
Consumptive Based Zakat 1 Pendahuluan 2 Tinjauan Pustaka.” Jurnal AlMuzara'ah 4, no. 1 (2016): 19-32.

Anggraini, Rachmasari, Ryval Ababil, and Tika Widiastuti. "Pengaruh Penyaluran Dana ZIS Dan Tingkat Inflasi Terhadap Pertumbuhan Ekonomi Indonesia Periode 2011-2015." FALAH: Jurnal Ekonomi Syariah 3, no. 2 (2018): 1. https://doi.org/10.22219/jes.v3i2.7231.

aravik, havis. Sejarah Pemikiran Ekonomi Islam Komtemporer. Depok: Kencana, 2017.

Az-Zuhaili, Wahbah. Fiqih Islam Wa Adillatuhu, 1982.

Chaudhry, Muhammad Sharif, and Suherman Rosyidi. Sistem Ekonomi Islam : Prinsip Dasar. Cet 1. Jakarta: Kencana Prenada Media Group, 2012.

Cingano, Federico. "Trends in Income Inequality and Its Impact on Economic Growth." OECD Social, Employment, and Migration Working Papers, no. 163 (2014): 0_1,5-59. https://doi.org/http://dx.doi.org/10.1787/5jxrjncwxv6j-en.

Kemenag. “Quran,” 2021.

Mubasirun, Mubasirun. "Distribusi Zakat Dan Pemberdayaan Ekonomi Umat." Inferensi 7, no. 2 (2013): 493. https://doi.org/10.18326/infs13.v7i2.493-512.

Nasrullah, Nasrullah. "REGULASI ZAKAT DAN PENERAPAN ZAKAT PRODUKTIF SEBAGAI PENUNJANG PEMBERDAYAAN MASYARAKAT (Studi Kasus Pada Baitul Mal Kabupaten Aceh Utara)." Inferensi 7, no. 1 (2015): 1. https://doi.org/10.18326/infsl3.v9i1.1-24.

Pambudi, Aji Hidayat. "Peran Zakat Produktif Dalam Pemberdayaan Masyarakat Miskin.” Fokus Bisnis 12, no. 2 (2013): 70-80.

Priyono, Sugeng. "Zakat Sebagai Instrumen Dalam Kebijakan Fiskal." Al Mashlahah Jurnal Hukum Dan Pranata Sosial Islam, 2017, 125-42.

Rozalinda. Ekonomi Islam: Teori Dan Aplikasinya Pada Aktivitas Ekonomi. Cet 2. Jakarta: Rajawali Pers, 2015.

Rudifachru. "Pembentukan Modal Dalam Pembangunan,” 2019.

Sarea, Adel. "Zakat as a Benchmark to Evaluate Economic Growth: An Alternative Approach." International Journal of Business and Social Science 3, no. 18 (2012): 242-45.

Sundari, Sundari. "Zakat Dalam Mendorong Pertumbuhan Ekonomi Dan Pengentasan Kemiskinan.” Al-'Adalah : Jurnal Syariah Dan Hukum Islam 3, no. 1 (2018): 23-35. https://doi.org/10.31538/adlh.v3i1.403.

Todaro, Michael P., and Stephen C. Smith. Economic Developement, 2012.

Wibowo, Sukarno. Dedi Supriadi. Ekonomi Mikro Islam. Bandung: CV. Pustaka Setia, 2017.

Widiastuti, Tika, and Suherman Rosyidi. "Model Pendayagunaan Zakat Produktif Oleh Lembaga Zakat Dalam Meningkatkan Pendapatan Mustahiq." Jurnal Ekonomi Dan Bisnis Islam 1, no. 1 (2015): 89-102. 